Available online at: http://proceeding.rsfpress.com/index.php/ic-smart/index

Proceeding on International Conference of Science Management Art Research Technology

(IC-SMART)

Volume 1 Number 1 (2020): 182-187

\title{
Corporate Social Responsibility Settings in Indonesia and India As A Comparison
}

\author{
Sri Bakti Yunari \\ Faculty of Law, Universitas Trisakti, Jakarta, Indonesia \\ E-mail address sri.by@trisakti.ac.id
}

\begin{abstract}
The article compares two mandatory-based regulations, which are different legal systems concerning Corporate Social and Environmental Responsibility (CSER) in Indonesia, as regulates by Chapter V, Article 74, Company Act 40/2007 juncto Government Regulation 47/ 2012. Afterward, the regulation of Corporate Social Responsibility (CSR) in India as regulated in Chapter IX, article 135, Companies Act 18/2013, and amendment juncto Companies (CSR Policy) Rule India, 2014. The research result was similarities and differences in settings substance between CSER and CSR. The similarities and differences found in comparative studies of the CSER act in Indonesia and CSR act in India are not influenced by the legal system of a country. Thus, it is more based on the similarity of the vision of both countries in understanding the importance of CSR in improving the quality of human life in order to actualize a welfare society.
\end{abstract}

Keywords: CSR, Setting, Comparison, Indonesia, India

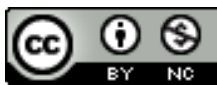

This is an open access article under the CC-BY-NC license

\section{INTRODUCTION}

Corporate Social Responsibility phenomena as mandatory in a global context is no longer a new thing in the $21^{\text {st }}$ century, especially in European and Asian countries. In Europe, France has implemented it through Nouvelles Regulations Economique in 2001 (Banteks Ilias 2004) and England through the 2003 CSR Bill. Indeed, the study for the development of legal framework idea in CSR as a practical concept and implementation has been put forward by CSR a Dutch CSR, Tineke Lambooy believing that "CSR is the backbone of the vision stated in the Earth Charter, that people must realize that people are one Earth community with the same destiny" (Tineke Lambooy, 2014). The earth Charter, born in the 21 st century, is a modern declaration of fundamental ethical principles for building a participatory, just, peaceful, and sustainable global society.

In addition to the study conducted by Tineke Lambooy of the development of CSR in Indonesia (Tineke Lambooy, 2014), an Australian CSR expert, Bryan Horrigan, has expressed his phenomenal opinion about 'the movement of CSR trends that is regulated in the $21^{\text {st }}$ century, including in Australia' (Bryan Horrigan 2007) and in Asian countries such as Indonesia and India.

The novelty of this article is developing a comparative study of mandatory CSR law in Indonesia and India, which has never been applied by CSR legal experts worldwide. Furthermore, the author has found articles that discuss CSR in some countries, as in India, after the introduction of the 


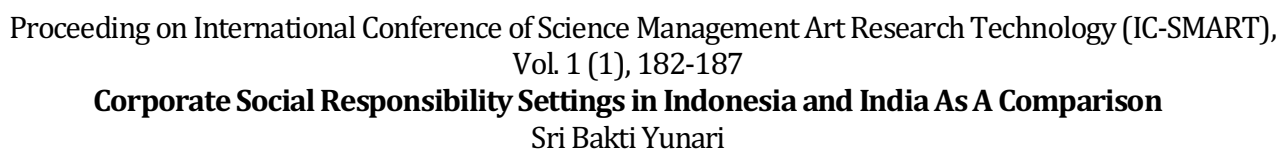

Companies Act of 2013 (e.g., Nava Subramaniam et al. 2017; Sandeep Gopalan and Akshaya Kamalnanth 2015).

Similarly, the articles have discussed CSR in Europe in the last eight years (e.g., Tinneke Lambooy 2014; Anna Remisova et al. 2013). In addition, the article discussed CSR in Indonesia after the enactment of the Companies Act 40 of 2007 (e.g., Patricia Rinwigati Waagstein 2010; Marina A Welker 2009). By comparing several CSR studies, the authors have found articles comparing CSR in India, Australia, and UK (e.g., Young, Suzanne and Thyil, Vijaya 2013). In addition, there are CSR comparison articles in Canada and the USA (Linda Thorne et al. 2015). Thus, This is an issue that will change the paradigm of voluntary into mandatory based CSR.

The purpose of this study is to describe CSR regulations in the two countries (Indonesia and India), which are both regulated in their respective company act, despite the application of different legal systems. This is interesting because Indonesia applies the civil law system, and India applies a common law system, yet both have made CSR mandatory in their company act. Thus, CSR concepts in the two countries have changed the nature of CSR, which has been adopted by western countries from voluntary to mandatory. Furthermore, the discussion in this paper will be discussing the differences between the material substances which regulate CSR in both countries.

\section{RESEARCH METHOD}

The methodology of research applied in this study is a legal research method, considered as doctrinal research (Anwarul Yaqin 2007), applying library-based research, then focusing on reading and analyzing the secondary material related to CSER and CSR regulation in Indonesia and India. Besides, for that reason, the study of CSR regulation in Indonesia and India is performed to produce legal reasoning as a prescription in solving legal issues faced. The CSR law materials are in the form of legislation, references, study results, and articles obtained from library studies in both countries, subsequently prescriptively analyzed, employing comparative approach as an instrument of learning and knowledge' (Mark Van Hoecke 2015). It is the process of identifying the regulations which govern activity and finding materials that explain or analyze those regulations. (Terry Hutchinson, 2002).

\section{RESULT AND DISCUSSION}

The substance of CSER Regulation in Indonesia

Currently, the regulation of CSR in the positive law of Indonesia is provided in three acts: (1) Article 2 and 88 State-Owned Enterprises Act 19/2003 and its delegation regulations, as well as through the State Enterprises Minister Decree PER-09/MBU/07/2015, PER-03/MBU/12/2016, and PER-02/MBU/7/2017 by using the term Partnership and Community Development Program; (2) Article 15 Investments Act 25/2007 by using the term CSR; and (3)in Chapter V Article 74 Company Act 40/2007, using the term of CSER (Tineke Lambooy, et al. 2014). In its development, the norms have been regulated at Local Regulations as well. Based on the research results, there are 115 Local Regulations on CSR (Sri Bakti Yunari et al. 2012).

Furthermore, the discussion focus of this paper is about CSER, which is regulated in the Company Act 40/2007. In general, the content of the Company Act 40/2007 will be outlined, consisting of 14 Chapters and 161 Articles. Thus, in formal juridical, in the Company Act 40/2007, the position of CSER is set forth in Chapter V Article 74 of the Company Act 40/2007. In interpretation act (general provisions) of the Company Act 40/2007, "a company is a legal entity consisting of a 
Proceeding on International Conference of Science Management Art Research Technology (IC-SMART),

Vol. 1 (1), 182-187

Corporate Social Responsibility Settings in Indonesia and India As A Comparison

Sri Bakti Yunari

capital partnership established based on a contract to carry out business activities with an authorized capital which is all divided into shares" (article 1 paragraph (1) of the Company Law 40/2007.

However, the definition of CSER as a legal concept is set forth in begripsbepaling (Maria Farida Indrati S 2008) or general provisions article 1, paragraph 3 of the Company Act 40/2007, stating that: "Social and Environmental Responsibility is the company's commitment to participate in sustainable economic development to improve the quality of life and the environment that is beneficial to the Company itself, the surrounding community, or the general public.""

In addition, CSER substance in Chapter V Article 74 of the Company Act 40/2007, which states that: "Corporations that carry out business activities in the fields and/or related to natural resources are required to carry out social and environmental responsibility. Thus, Social and Environmental Responsibility is a company obligation that is budgeted and calculated at the expense of the corporation, the implementation of which is carried out with due observance of compliance and regularity. Furthermore, companies that do not carry out their obligations will be subject to sanctions in accordance with the prevailing laws and regulations". As its implementation, in 2012, the government has issued the implementing regulation by GR 47/2012, as the existence of the implementing regulation more confirms the position of CSER as mandatory and must be implemented in Indonesia. CSER regulation, especially applied to companies conducting business activities in the fields or related to natural resources, has caused debate among companies.

On the one hand, the company states that CSER is the same as CSR. On the other hand, the government states that CSER is different from CSR as stated in the Verdict of the Constitutional Court 53/PUU-VI/2008 on Subject Trial by Company Act 40/2007 on April 15, 2009, over a class action against the Constitutional Court on the existence of Article 74 the Company Act 40/2007 is as follows:

First, CSER is legally obliged only to companies carrying out business activities in the field of natural resources and or related to natural resources. However, CSR, in general, is required to all companies;

Second, CSER costs by the company are charged to operating costs, the amount of which is determined based on reasonableness and fairness. Meanwhile, the cost for CSR by the company is calculated from the company's net profit;

Third, violations of the non-implementation of CSER will be subject to sanctions as stipulated in the relevant sectoral laws and regulations. For example, a company violating environmental regulations is subject to the applicable sanctions set forth in Protection and Management of Living Environment Act 32/2009, or if the violation concerns the provisions of Forestry Act No. 41/1999, the sanctions shall be in accordance with the provisions of sanctions as regulated in it. In contrast, sanctions for violation of CSR is only a moral sanction.

Based on the statement in the decision of the Constitutional Court, then juridically, CSER is different from CSR, but according to the author, the government statement in consideration of the decision is contradictio in terminis (inconsistency because the concept of CSER in the general provision of Article 1 paragraph 3 in the Company Act 40/2007 is a substantial concept perceiving that of the CSR of World Bank version whose version has been followed and applied by western countries, which in fact is voluntary. The inclusion of the World Bank CSR concept as a general definition of CSER in the general provisions of the Company Act 40/2007 indicates that CSER conceptually is identical with CSR because the general provision of the legislation is a definition which becomes the concept of CSER, which will be regulated in the substance of the Act. 
Proceeding on International Conference of Science Management Art Research Technology (IC-SMART),

Vol. 1 (1), 182-187

Corporate Social Responsibility Settings in Indonesia and India As A Comparison

Sri Bakti Yunari

According to the theory of legislation, if a legal product, in this case, the legal product of CSER stipulated in Article 74 of the Company Act 40/2007, normatively contradicts the general provision as the legal concept of CSER in Article 1, paragraph 3 of the Company Act 40/2007. It can be said that the regulation of CSER is ineffective. The legislator should refer to and draft its own version of CSER in accordance with the values incorporated in Pancasila and the 1945 Constitution and Amendment as proposed by the Founding Fathers or Framers of the Constitution to form its own system, avoiding the influence of individualism and liberalism (Bagir Manan 2012). Ideally, if the CSR will be legislated into a separate act, then the definition of CSR as set forth in the general provision is a definition of CSR based on the Concept of Economic Democracy Pancasila in accordance with the Indonesian legal character and legal culture, to avoid the fallacy of ambiguity (B Arif Sidharta 2014).

The substance of CSR Regulation in India

Based on the CSR concept in India equalized with the Mahatma Gandhi's 'Trusteeship model' of CSR (Nayan Mitra and Rene Schmidpeter) followed by major companies in India, this CSR model is a part of cultural heritage in India. Although the term CSR is relatively new, the CSR concept itself has existed for more than a century (Janalaksmi 2001; Nikunj Keyal 200). There are several terminologies other than CSR in India, which are Corporate Citizenship, Corporate Responsibility, Responsible Business, and Sustainable Responsible Business, or Corporate Social Performance. Several definitions of CSR in India defined that: "CSR or simply CSR is the obligation of the companies to protect and enhance the norms and values held by the society" (Partha Sarathi 2011). Other opinion stated that: "CSR is a concept in which a corporate organization considers the interests of the community more by being accountable for the impact of its business activities on employees, shareholders, suppliers, customers, the community and direct and indirect stakeholders as well as the environment" (Ayesha Malhotra 2017).

In other words, "the CSR approach is holistic and integrated with the core business strategy for addressing social and environmental impacts of businesses. CSR needs to address the well-being of all stakeholders and not just the company's shareholders. Philanthropic activities are only a part of CSR, which otherwise constitutes a much larger set of activities entailing strategic business benefits".

Based on the content of the Companies Act 18/2013 that consists of 7 Schedules, 29 Chapters, and 470 Article, CSR provisions are specifically stipulated in Chapter IX on Account of Companies, Article 135 (section 135) and The Companies Act 18/2013, enforced on August 29, 2013. Currently, the Article 135 Companies Act 18/2013 has been amended in 2017 by the Companies (Amendment) Act 1/2018 dated January 3, 2018. In article 135, the sub-article (1) states that: 'for the words "any financial year", the words 'previous financial year' should be substituted. Then, companies are not required to appoint independent directors because in its CSR Committee, there are two or more directors'. Furthermore, for the words and figures "as specified in Schedule VII", the words and figures "in areas or subject, specified in Schedule VII" shall be substituted. Additionally, the following elucidation shall be substituted, in which 'net profit' shall not include such sums as may be prescribed and shall be calculated in accordance with the provisions of article 198 on calculating profit.

To implement CSR programs in India, companies are required to make a list of CSR activities program as stipulated in the Schedule VII amendment. The Companies Act 18/2013 juncto Companies (CSR Policy) Rules 2014 states that: "The definition of CSR includes but is not limited to projects or programs (i) As specified in the activities specified in the Companies Act 2013 


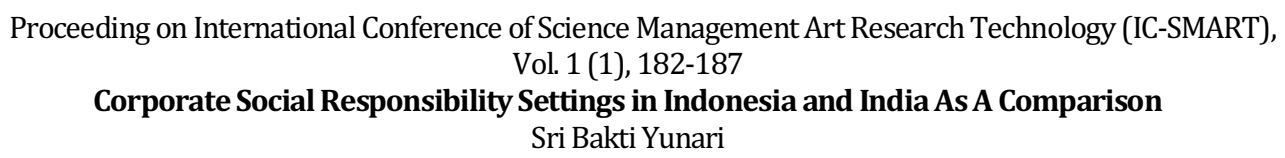

Schedule VII or (ii) activities carried out by the company's board of directors (Board) based on recommendations from the CSR Committee Board based on the company's CSR Policy, provided that the policy will be covers subjects as stipulated in the Company Law 18/2013 schedule VII".

Based on the previous provisions, it is clear the Indian CSR Act expressly regulates the forms of CSR program which must be implemented by companies. Moreover, if the CSR program undertaken by the company is outside the said provision, then the company will be deemed as not implementing the CSR program. Likewise, companies which do not undertake CSR will impliedly be subject to sanction. The sanction is provided in Chapter XI (Appointment and Qualifications of Directors) - Article 166 and 172, The India Companies Act 18/2013.

\section{CONCLUSION}

In conclusion, the CSR settings in Indonesia and India are not influenced by the legal system of a country. Thus, it is more based on the basic philosophy of both countries in understanding the importance of CSR in improving the quality of human life in order to actualize the welfare society. Moreover, although both Indonesia and India have regulated CSR in their company acts, there are three differences by principles in Indonesia and India settings.

\section{REFERENCES}

Anna Remisova et.al. 2013. CSR in Europe. Journal of East European Management Studies 18-4: 512-542.

Anwarul Yaqin. 2007. Legal Research and Writing. Malayan Law Journal Sdn Bhd-Lexis Nexis.

Ayesha Malhotra, et.al. 2017. Multi-Level Corporate Responsibility: A Comparison of Gandhi's Trusteeship with Stakeholder and Stewardship Framework. Journal of Business Ethics 141, 133 136.

B. Arif Sidharta. 2014. Pengantar Logika - Sebuah Langkah Pertama Pengenalan Medan Telaah. Jakarta, Refika Aditama Publishing.

Bagir Manan. 2012. Membedah UUD 1945, Editor Moh Fadli. Malang: Penerbit UB Press, Cetakan ke-1.

Illias Bantekas. 2004. CSR In International Law. Boston University International Law Journal, 309 22.

Bryan Horrigan. 2007. 21st Century CSR Trends - An Emerging Comparative Body of Law and Regulation on Corporate Responsibility, Governance, And Sustainability. 4 MqJBL.

Phoebe C. Ellsworth. 2005. Legal Reasoning (The Cambridge Handbook of Thinking and Reasoning, K. J. Holyoak and R. G. Morrison Jr. (eds), (New York, Cambridge Univ. Press.

Gregory Jackson and Androniki Apostolakou. 2010. CSR in Western European Institutional Mirror or Subtitute. Journal of Business Ethics 94 371-394.

Linda Thorne, et al. 2017. A Comparison of Canadian and U.S. CSR Strategic Alliances, CSR Reporting, and CSR Performance: Insights into Implicit-Explicit CSR. Journal of Business Ethics 143: 85-93

Maria Farida S. Indrati. 2008. Ilmu Perundang-undangan - Proses dan Tehnik Pembentukannya, Penerbit Kanisius.

Marina A. Welker. 2009. Corporate Security Begins in the Community-Mining the CSR Industry and Environmental Advocacy in Indonesia. Cultural Anthrophology 24-1: 142-179

Mark Van Hoecke. Methodology of Comparative Legal Research. 2015. LaM DOI:10.5553/REM/.000010. 
Nava Subramaniam et. Al. 2017. Governance of Mandated CSR: Evidence from India GovermentOwned Firms. Journal of Business Ethics 143: 543-563

Nayan Mitra, René Schmidpeter. CSR in India - Cases and Developments After the Legal Mandate (1st, edn, Springer International Publishing Switzerland. 2017. <eBook ISBN 978-3-319-417813, DOI 10.1007/978-3-319-41781-3, Hardcover ISBN 978-3-319-41780-6, Series ISSN 21967075

Partha Sarathi Adhya. 2011. CSR: The Indian Trend in Dipak Das dan Sanjay Kumar Singh, Corporatization and CSR - Insurance, Banking, Industrial Design, Ownership and Control (SBS Publisher \& Distributors Pvt, Ltd, New Delhi, 39.

Patricia Waagstein Rinwigati. 2011. The Mandatory CSR in Indonesia: Problems and Implications. Journal of Business Ethics 98: 455-466

Rodolfo Sacco. 1991. Legal Formants: A Dynamic Approach to Comparative Law. The American Journal of Comparative Law 39 (1) (Installment I of II)' 1-34.

Sandeep Gopalan \& Akshaya Kamalnath. 2015. Mandatory CSR as a Vehicle for Reducing Inequality: an Indian Solution for Piketty and The Millennials. Journal of Law and Social Policy, 1 Northwestern 10.

Sri Bakti Yunari et. al. 2014. An Inventory of Enactment CSR as a Legal Obligation for the Corporations in Indonesia. The Reports of Research, Grants Competition Research, Funded by The Ministries of Research, Technology, And Higher Education Republic of Indonesia.

Suzanne Young and Vijayal Thiyil. 2014. Journal CSR and Corporate Governance: Role of Context in Internastional Settings. Journal of Business Ethics 122: 1-24

Terry Hutchinson. 2002. Researching and Writing in Law (Law Book Co Pyrmont)

Tineke Lambooy et.al. 2014. CSR in Indonesia - Legislative Development and Case Studies (Konstitusi Press, Jakarta) 